\title{
SOCIAL MEDIA NEWS: MOTIVATION, PURPOSE AND USAGE
}

\author{
Samaneh Beheshti-Kashi and Baharak Makki \\ Department of Engineering, Faculty of Technology and Science, University of Agder, \\ Grimstad, Norway \\ baharak.makki@uia.no
}

\begin{abstract}
This paper presents the results of an online survey which was conducted to analyse the use of social web in the context of daily news. Users' motivation and habit in the news consumption were focused. Moreover, users' news behaviour was distinguished in three purposes such news consumption, news production and news dissemination to find out if the usage has a passive or active character. In a second step it was questioned which social software is used for which purpose. In conclusion users appreciate social software for features such as interactivity and information that traditional media does not provide. Among the social web platforms users prefer social networking sites as well as videoshare platforms. Social networking sites also rank first in the news production and dissemination.
\end{abstract}

\section{KEYWORDS}

Social media news, daily news, news consumption, news production, news dissemination

\section{INTRODUCTION}

The web is an emerging source of current news. In 2002, $48 \%$ of the web users stated that they use the internet often/occasionally to access in daily news. In 2011 this increased to $61 \%$ [1]. Currently internet is an essential source of daily news. However in the web there are numerous instruments enabling users to access in daily news.

On the one hand there are online formats of TV and radio channels as well as of newspapers and magazines. On the other hand there are newspapers and magazines that are exclusively published online. In the context of this paper all these formats are categorised as traditional media. In contrast to traditional media, a new trend has emerged where ordinary web users publish information. Tools and platforms such as weblogs and social networking sites give users the chance to share, comment, publish, produce any kind of information online; where the sole requirement is to have internet access. Compared to the traditional media here, users adopt an active role in news production and may act such as journalists or editors.

This paper investigates news seeking behavior in the Web 2.0 context with the help of an online survey. Motivations underlying users' preferences have been examined.

\section{SOCIAL SOFTWARE}

Literature offers limited number of definitions for the term "Social Software". Alby [2] describes social software as systems that allow users to communicate, collaborate and interact with each DOI : $10.5121 /$ ijcsit.2013.5209 
other. However according to this definition a SAP-System would also be categorised as a social software knowing that many people can communicate via this system. There Alby improve its definition and suggests social software to enable community building process as well [3]. Lastly Alby differentiates two different categories of social software [4].

1. In the first category of social software communication is the main aspect.

2. Whereas the second category social software focuses on the user and collectively produced content. Therefore the community aspect is the main point of this category.

For the purpose of this paper the second category will be the guiding aspect of social software where users play an active role in the production.

Schmidt [5] classifies Social software in the following four categories:

1) Personal Publishing

2) Platforms

3) Information management tools

4) Wikis

The following formatting rules must be followed strictly. This (.doc) document may be used as a template for papers prepared using Microsoft Word. Papers not conforming to these requirements may not be published in the conference proceedings.

\subsection{Personal Publishing}

Personal Publishing tools provide users the possibility to publish content online [6]. Articles in these tools can directly be published. Therefore there is no such a filter function in these tools [7]. The main tools of this category are weblogs and microblogging services. The word weblog comes from the words "web" and "logbook" [8]. Merriam Webster describes weblog as "a website that contains an online personal journal with reflections, comments, and often hyperlinks provided by the writer;" [9]. There are different types of blogs such as private blogs, corporate blogs and media blogs [10]. In the context of daily news there are blogs which are critical to the traditional media for example the spiegelkritik.de . Another genre which is especially spread in the USA is warblogs. This kind of blogs has emerged with wars in Afghanistan and Iraq [11]. Warblogs are good illustrations of Social software in use of a source of daily news.

On the other hand a subcategory, microblogs, let users to publish content in a limited way [12]. Twitter is most well known microblogging service. Back in 2009 when a passenger took the pictures an emergency landing and posted in real time in Twitter O'Reillys to celebrated Twitter as "the world's real-time newspaper" [13]. This example supports the thesis that microblogging services could play an essential role on the news seeking attitude.

\subsection{Platforms}

Schmidt describes platforms as applications that enable users an infrastructure for communication and interaction. The very feature element of platforms is that the user has to be a registered member of the platform in order to produce and share content. Schmidt proposes to divide the platforms in two groups: the multimedia platforms and the social networking platforms. In the group of the multimedia platforms we can state video, photo or audioshare platforms [14]. YouTube is the most successful videoshare platform worldwide and is one of the biggest websites for three years [15]. YouTube have been ranked in third position in Alexa global website ranking [16]. Numerous online phenomenons have proved that YouTube is a news source especially when 
eye witnesses upload videos relating to news events, in this cases traditional media needed to refer to YouTube. In 2009 during political unrest in Iran YouTube and Twitter were the only news source and even traditional media adapted their reporting to YouTube [17].

Another widely spread platform are social networking platforms or social networking sites. User has to register and develop their personal profile in order to interact with other users [18]. Among the social networking sites Facebook is the most successful and ranked in first place at the 500 Top sites worldwide [19]. Mark Zuckerberg, the founder of Facebook once said, that in the last 100 years journalists decided for the people which news are worth to be reported about. Now with platforms like Facebook people decide for themselves. He added that he trust an article or information more when it is recommended or written by a friend than by a random journalist that you even do not know [20].

\subsection{Information management tools}

The information management tools have their focus more on supporting the information management than on communication or producing content [21]. Examples for these tools are social bookmarking services as digg and social newsrooms such as yigg.

\subsection{Wikis}

The wiki technology allows registered users to edit existing articles. In this form of social software the community takes over the role of an editor and assures somehow a certain level of quality [22]. The technology gained his first success with the raise of Wikipedia [23]. Additionally Wikinews that focuses in daily news was created in 2004.

\section{RELATED WORK}

The Pew Research Center's Project for Excellence in Journalism discussed Americans' reliance on social media in their daily news seeking. Accordingly 9\% of interviewees stated that they receive news through Facebook or Twitter very often. 36\% of interviewees visit news websites or apps regularly. Excluding people who do not receive news online at all, the percentages raise from $9 \%$ to $52 \%$ and from $36 \%$ to $92 \%$. Accordingly $92 \%$ of online users still visit news websites. Social media users keep visiting the news websites/applications for the daily news. Therefore, Pew Research Center concludes that the traditional media still dominate, followed by Facebook and then by Twitter. Authors state that social media are additional paths to news, not replacement for more traditional ones [24].

Another survey reveals that only $7 \%$ of the users seek for news on a daily basis in communities. Whereas $62 \%$ stated that they never get their daily information in such platforms [25].

\section{EMPIRICAL STUDY}

An online survey was conducted on the news seeking behaviour in the context of social web to collect data for our analysis. The survey consists of 22 questions. This paper focuses below three questions:

Question 1: Do users integrate social software in their daily news seeking?

Question 2: What are the reasons and motivations that underlie users' preferences relating to use of the social web in the context of daily news? 
Question 3: Which are the preferred platforms/tools/services in this context?

Question 4: For which purpose is social software used in this context?

Question 5: Which are the preferred platforms/tools/services for the purposes news consumption, news production and news dissemination?

Overall 271 respondents have taken part in the online survey. Only 201 of the forms have been completed and thus valid. From the 201 participants $71 \%$ were female and $29 \%$ were male. The age distribution is as follows:

$\begin{array}{ll}- & 13-20: 11.4 \% \\ - & 21-30: 77.6 \% \\ - & 31-40: 9.0 \% \\ - & 41-50: 2.0 \%\end{array}$

Professional distributions are as follows:

- $\quad$ Student: $58.2 \%$

- $\quad$ Professional: $25.4 \%$

- $\quad$ Pupil: $11.9 \%$

- $\quad$ Other: $4.5 \%$

The first research question revealed that among 180 participants who check online sources for daily news, 90 stated that they integrate social web in their routine of news seeking whereas the other 90 participants negated this question. To get insights on motivations underlying users' preferences, participants have been split into two equal groups of users and non-users of social media. The group of non-users replied 7 questions in a five-level Likert scale while the group of social media users answered to 5 different statements. Participants are allowed to replies as agreed, disagreed or no answer.

\subsection{Motivations}

Data reveals that the main reason for not using the social web as a source for current news is that 'anybody can write an article and publish it'. $82.2 \%$ of the non-users do not intend to use social media as the articles are not written by qualified journalists.

Another argument that disfavour social media content that it tends to be subjective and even personal. Additionally $66.7 \%$ of non-users distrust social media content because it is not reviewed and approved by an authority. Non-users are sceptical of the truthfulness of news coming from social media. To sum up non-users of social media intentionally avoid the content generated by the users, which is the central element of social media.

Other factors such time and accessibility demotivates users to adopt social media as well. Data reveals that $29 \%$ of the participants think that getting news from social web is time consuming. And $43 \%$ of them think that searching for news in web platforms is very difficult.

When analysed user group data, $67 \%$ of social web users appreciate the variety of information that is not offered by the traditional media thus integrates social web in the news seeking process. Users prefer to choose news channels among a larger source and to by-pass traditional media that act such 'gatekeeper'. Users of social media like to decide the importance and the relevance of an 
event by their own and dislike that traditional media filter the news for them. Similarly $67 \%$ of the users like to be exposed to the different perspectives that social web offers.

Additionally $66 \%$ of social media users stated that social web offers deeper background information of a topic compared to traditional media does.

Almost half of the users marked that they access to social web platforms in order to get information directly from eye witnesses. Especially in the raising of smartphones this argument is getting more relevant.

Finally web platforms offer interactivity between users and the content. In social web users participate in discussions and shares their opinions with others. Dan Gilmore compares this new form of journalism with conversation or seminar [26]. Users that have already accustomed to interactive feature of social web applied it in the context of daily news as well.

To conclude web media users like the social media for features that traditional media does not provide thus social media is perceived as an additional path to the traditional media.

\subsection{Preferred Social Software}

The data reveals that social networking sites play a major role on news seeking process. $78 \%$ of social web users seek news via these platforms. As described in 2 Social Networking Sites, especially Facebook, gained a lot of success in the last years by attracting extensive public interest.

Besides social networking sites, video sharing platforms functions as new platform as well. 55\% of the respondents stated that they acquire news through video sharing platforms. This figure might be explained with the remarkable success of YouTube which is ranked third on the Top 500 sites rankings [27].

Wikis (39\%), weblogs (36\%) and microblogging services rank similarly and are used from roughly more than one third of the users. The fact that Wikis rank on the third place may be expected with news sites like Wikinews and Wikipedia. Knowing that these are relatively mature news platform these are surprisingly ranked in lower rank in our survey.

Although microblogging services belong to the newer generation of social software, $31 \%$ of the users quoted that they acquire daily news through such services. Also this result might be explained with the success of a sole provider: Twitter ranked on 10th among Top 500 site rankings [28].

Social bookmarking services (13\%), newsrooms (11\%) and photoshare platforms $(11 \%)$ are adopted roughly by $10 \%$ of users. The result of social bookmarking services and newsrooms might be explained with their quiet new existing. The low user figures for photo-platforms may be related to the fact that most news articles include already pictures. Therefore the search in these platforms costs additional work and time. However in some cases like natural disasters the extra work might be worth to get greater insights about the catastrophe.

In summary social networking sites and video sharing platforms i.e. Facebook and YouTube have widely adopted in the context of daily news. However weblogs and specially microblogging services such as Twitter should not be neglected in this context. 


\subsection{Purpose}

In the last section we analyzed the usage of Social Software. A further step which will be discussed in this section is in which way or for which purpose social software is accessed in the context of news. With this approach we can also find out if social web usage in this context more active or passive. Therefore we differentiate between three following purposes:

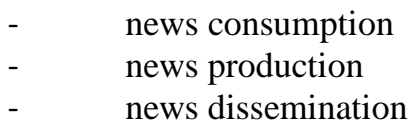

News consumption is the reading of articles or watching videos/pictures which is a more passive behavior. Whereas the news production is a more active habit as it includes writing articles and participating in discussions. The answer item "participating in a discussion" was pointed out separately as it is a key feature of social media and stands for its interactivity. Also news dissemination is an active behavior since it implies sharing and forwarding news articles, links or videos/pictures.

The figures reveal that users access to social web predominantly for their news consumption. The possibility to be an active member is used by few users. Also the sharing and forwarding of daily news is merely a purpose when accessing social web. This result could be caused because of the following facts:

Publishing articles or taking part in a discussion is always more time consuming and takes also extra work. Therefore it seemed that not all users are willing to accept this additional work. Since sharing or forwarding takes also extra time and work this argument could also be applied to the result of the news dissemination.

Moreover, it could be argued that the user still have to adapt his new role in the news process which includes a more active and participating user behavior. This is the main reason why the changing media landscape is often characterized as follows: „It focuses on the process more than the product" [29].

Overall we can state that the users' behavior towards social media news is still more passive since the user access social web for its news consumption. However, the possibility to publish and disseminate news is perceived by few users, we assume that there is a high potential in this area, as the user will more and more adapt to his new role and develop a more active social media news habit.

\subsection{Preferred Social Software for news consumption, production and dissemination}

In question research 3 we analyzed the usage of social software in general. In the previous section the purpose was focused. Now we want to combine both questions to find out which software is used in which context/ for which purpose.

Videoshare platforms are accessed from $36,7 \%$ of the users in order to get news. About one-third $(33,3 \%)$ of the respondents state that they use social networking sites for their daily news consumption. Also wikis are used from $33,3 \%$ for this purpose. Weblogs are taken into account from $25,6 \%$. One in five $(20 \%)$ get news from microblogging services like Twitter. The percentages for the other tools are under $10 \%$ : newsrooms $(7,8 \%)$, photoshare platforms $(4,4 \%)$, social bookmarking services $(2,2 \%)$. The figures for the news consumption are relatively high compared to the figures for news production and news dissemination. Especially in the case of 
videoshare platforms we find high differences: Whilst it is the most used platform in the consumption routine, only $2,2 \%$ produce or publish videos in these platforms.

As we already stated news production always takes additional work. This extra effort applies especially to the production of videos. Therefore this result seemed not to be surprising. However with the rise of smartphones and the mobile web videoshare platforms should not be neglected. Dave Sifry, the founder of the blog search engine Technorati applies the videoshare platforms a special role in the news process: "Just wait till people understand the power of the mobile phone it's got a camera, a microphone, an ear piece and a display - then you have a broadcast device in your hand" [30].

Social networking sites rank at the first position $(24,4 \%)$ in the news production. This result could be explained with different characteristics of these platforms: Most social networking sites give their users the possibility to publish a status message. This function is originally for publishing what the user is currently doing. However this function could also be used to post news information. In Facebook for example the user status message will be shared and shown on every friend's site. Therefore the production and dissemination is more or less done in one move. The figures for production $(24,4 \%)$ and dissemination (20\%) in social networking sites differ only by $4,4 \%$ which may be explained by the described functionality.

In addition, social networking sites have the function to found groups. Within these groups user can participate in discussions. $13,3 \%$ of the respondents said that they take part in discussion in these sites. Also this figure is the highest within the item participation in discussion compared to the other applications. Despite the relative low figures for news production and dissemination we assume that social networking sites are used in a passive but also in active manner. In the last years examples like the uprising in Iran 2009 or the Arab spring has shown that Facebook was a way to keep the public updated by actively publishing content.

Personal publishing services are both used in a passive way. Microblogging services are only accessed by $6,6 \%$ to publish news information or participate in discussions. Also Weblogs are used by only few $(7,8 \%)$ users for this purpose. Likewise are the figures within the news dissemination. Only 4,4\% (microblogging services) and 2,2\% (Weblogs) share or forward content within these services.

Social bookmarking services show one characteristic compared to the other tools and platforms. It is the only service whose figures for news dissemination are higher than production and consumption. This could be explained with the fact that these services were originally designed to bookmark interesting and worthy content in order to make them public. Therefore the main focus is on the news dissemination. Thus this result should not be a surprising.

As already stated in question research 3 Newsrooms take a minor role in the users' news behavior within the context of social media. This fact can be confirmed with the figures for news production $(3,3 \%)$ and dissemination $(0 \%)$.

Similar to Newsrooms are the figures for photoshare platforms. Only $4,4 \%$ access them to publish news information. The percentage for the dissemination is even lower with only $2,2 \%$.

In conclusion it can be stated that user tend to integrate videoshare platforms, social networking sites and wikis for the news consumption. Whereas for the news production and dissemination the use of social networking sites seems to be more common. However these results should be treated carefully and questioned in further studies with more participants. 


\section{CONCLUSIONS}

Conducted online survey reveals two districts group of user and non-user of social media. Nonusers intentionally avoid content generated by the users, which is the central element of social media. Non- users are sceptical of the truthfulness of news coming from social media.

On the other hand users of social media like to decide the importance and the relevance of an event on their own and dislike that traditional media filter the news flow for them.

To conclude web media users like social media platforms for features such as interactivity and diversity that traditional media does not provide thus social media is perceived as an additional path to the traditional media than being its alternative.

Especially with the rise of smartphones, development of their video cameras, and the mobile web reports of eye witnesses will get more and more relevance as they can upload their videos of an event or accident in real time in one of their social web accounts.

Social networking sites and video-sharing platforms such Facebook and YouTube play a major role in social media followed by micro-blogging service, Twitter.

It seems that user access social web in a passive habit since they use the social web predominantly for their news consumption. However, publishing and dissemination news should not be neglected as it stands for the interactivity of the new web.

Additional research can be done to reveal whether device (PC, laptop, tablet, smartphone) influence the news seeking behaviour. Do smartphone users tend to use social media while PC users prefer traditional media?

Another interesting aspect of the social media is the community effect; whether an event perceived more relevant and credible when published by a friend.

Further studies on these questions will allow us to have a better understanding of the changing media landscape, the new role of the user in the news process as well as the power and dynamics of networks.

\section{REFERENCES}

[1] ARD/ZDF-Onlinestudien 2004-2012. Available on: www.ard-zdfonlinestudie.de/index.php?id=onlinenutzunginhalt0 [Accessed 03 January 2013]

[2] Alby, T., Web 2.0. Konzepte, Anwendungen, Technologien, Carl Hanser Verlag, 2007, p. 89.

[3] Alby, T., Web 2.0. Konzepte, Anwendungen, Technologien, Carl Hanser Verlag, 2007, p. 89.

[4] Alby, T., Web 2.0. Konzepte, Anwendungen, Technologien, Carl Hanser Verlag, 2007, p. 90.

[5] Schmidt, J., Das neue Netz. Merkmale, Praktiken und Folgen des Web 2.0, UVK Verlagsgesellschaft, 2009, p. 22.

[6] Schmidt, J., Das neue Netz. Merkmale, Praktiken und Folgen des Web 2.0, UVK Verlagsgesellschaft, 2009, p. 22.

[7] Hoem, J.; Schwebs, T., Personal Publishing and Media Literacy,IFIP World. Conference on Computers in Education (WCCE 2005), 2004, 3. Available on: http://infodesign.no/artikler/personal_\%20publishing_media_literacy.pdf [Accessed 03 January 2013]

[8] Löwenberg, B., Web 2.0: Prinzip, Technologien und Einsatzszenarien- ein Überblick. In: Informationskompetenz 2.0. Zukunft von qualifizierter Informationsvermittlung. 24. Oberhofer Kolloquium zur Praxis der Informationsvermittlung im Gedenken an Joseph Weizenbaum, 2008, pp.21-34.

[9] Merriam Webster, 2012. An Encyclopaedia Britannica Company, Available on: http://www.merriamwebster.com/dictionary/blog [Accessed 03 January 2013] 
International Journal of Computer Science \& Information Technology (IJCSIT) Vol 5, No 2, April 2013

[10] Zerfaß, A., Bogosyan, J., Blogstudie 2007, Informationssuche im Internet- Blogs als neues Recherchetool (Ergebnisbericht). Available on: http://www.cmgt.unileipzig.de/fileadmin/cmgt/PDF_Publikationen_download/Blogstudie2007- Ergebnisbericht.pdf [Accessed 03 January 2013]

[11] Schulz-Bruhdoel, N., Bechtel, M., Medienarbeit 2.0. Cross-Media-Lösungen ; das Praxisbuch für PR und Journalismus von morgen. FAZ-Inst. für Management-, Markt- und Medieninformationen, 2009, pp.63-64.

[12] Simon, N., Bernhardt, N., Twitter. Mit 140 Zeichen zum Web 2.0, Open Source Press, 2008, p. 13.

[13] O’Reilly, T.; Milstein, S.; The Twitter Book, O’Reilly Media, 2009, p. 13.

[14] Schmidt, J., Das neue Netz. Merkmale, Praktiken und Folgen des Web 2.0, UVK Verlagsgesellschaft, 2009, pp. 22-23.

[15] Alby, T., Web 2.0. Konzepte, Anwendungen, Technologien, Carl Hanser Verlag, 2007, p. 111.

[16] Alexa The Web Information Company, 2013. Available on: www.alexa.com/topsites

[17] Hengstenberg, Claudine, Twitter-Revolution im Iran. Der virtuelle Protest nach den Wahlen, Fastbook Publishing, 2009.

[18] Schmidt, J., Das neue Netz. Merkmale, Praktiken und Folgen des Web 2.0, UVK Verlagsgesellschaft, 2009 , p. 9.

[19] Alexa The Web Information Company, 2013. Available on: www.alexa.com/topsites

[20] Schulz-Bruhdoel, N., Bechtel, M., Medienarbeit 2.0. Cross-Media-Lösungen ; das Praxisbuch für PR und Journalismus von morgen. FAZ-Inst. für Management-, Markt- und Medieninformationen, 2009, p.58.

[21] Schmidt, J., Das neue Netz. Merkmale, Praktiken und Folgen des Web 2.0, UVK Verlagsgesellschaft, 2009 , p. 26.

[22] Löwenberg, B., Web 2.0: Prinzip, Technologien und Einsatzszenarien- ein Überblick. In: Informationskompetenz 2.0. Zukunft von qualifizierter Informationsvermittlung. 24. Oberhofer Kolloquium zur Praxis der Informationsvermittlung im Gedenken an Joseph Weizenbaum, 2008, pp.21-34.

[23] Schmidt, J., Das neue Netz. Merkmale, Praktiken und Folgen des Web 2.0, UVK Verlagsgesellschaft, 2009, p. 25.

[24] PEW RESEARCH CENTERS PROJECT FOR EXCELLENCE IN JOURNALISM, 2012 STATE OF THE NEWS MEDIA. Available on: http://stateofthemedia.org/2012/mobile-devices-and- newsconsumption-some-good-signs-for-journalism/what-facebook-and-twitter-mean-for- news/ [Accessed 04 January 2013].

[25] ARD/ZDF-Onlinestudien 2004-2012. Available on: www.ard-zdf-onlinestudie.de/index.php?id=356 [Accessed 04 January 2013].

[26] Gillmor, D., We, The Media: Grassroots Journalism by the People, for the People, O'Reilly Media, 2004.

[27] Alexa The Web Information Company, 2013. Available on: www.alexa.com/topsites

[28] Alexa The Web Information Company, 2013. Available on: www.alexa.com/topsites

[29] Deuze, M., Professional identity in a participatory media culture. In: Quandt,T., Schweiger, W.: Journalismus online- Partizipation oder Profession? Verlag für Sozialwissenschaften, 2008, pp.251261.

[30] Yeomans, M., The birth of Wikinews, Citizen's Kane, Available on: http://citizenskane.blogspot.de 